\title{
Analisis Kendala Penerapan Pendekatan Saintifik dalam Pembelajaran Barisan dan Deret Geometri
}

\section{Huriah Hasanah', Puji Nugraheni² and Riawan Yudi Purwoko³}

1,2,3Program Studi Pendidikan Matematika Universitas Muhammadiyah Purworejo

Corresponding Author: huriahhasanah@gmail.com

DOI: http://dx.doi.org/10.15294/kreano.v1 1i1.20663

Received : January 1 2019; Accepted: November 20 2019; Published: June 12020

\begin{abstract}
Abstrak
Penelitian ini bertujuan untuk menganalisis kendala penerapan pendekatan saintifik dalam pembelajaran barisan dan deret geometri. Sumber data terdiri dari data primer yaitu siswa yang diambil dengan teknik snowball dan data sekunder yaitu guru. Teknik pengumpulan data menggunakan observasi, wawancara, dan dokumentasi. Teknik analisis data terdiri dari reduksi data, penyajian data, dan penarikan kesimpulan. Teknik pemeriksaan keabsahan data menggunakan triangulasi teknik. Berdasarkan hasil penelitian disimpulkan bahwa kendala penerapan pendekatan saintifik dalam pembelajaran barisan dan deret geometri berupa: (1) kendala dalam menanya yaitu merumuskan pertanyaan terkait banyaknya suku, jumlah suku pertama, serta rasio; (2) kendala dalam mengumpulkan informasi yaitu kurang optimalnya penggunaan buku teks dan internet; (3) kendala dalam mengasosiasi yaitu menentukan banyaknya suku dan menentukan rumus barisan dan deret; (4) kendala dalam mengkomunikasikan yaitu membaca kalimat matematika perkalian dan akar.
\end{abstract}

Kata Kunci: pendekatan ilmiah, kurikulu 2013, baris dan deret

\begin{abstract}
This study aims to analyze the constraints of implementation scientific approach in the learning of geometric sequences and series. Data sources consist of primary data is students uses snowball techniques and secondary data is teachers. Data collection techniques using observation, interview, and documentation. Data analysis techniques used data reduction, data display, and conclusion drawing. The data validity inspection technique used triangulate technique. Based on the results of the study concluded that constraints of implementation scientific approach in the learning of geometric sequences and series is: (1) constraints in questioning is to formulate questions related to the number of tribes, the number of first tribes, and ratio; (2) constraints in collecting information is less optimal use of textbook and internet; (3) constraints in associating is determining the number of tribes and determining the sequences and series formula; $(4)$ constraints in communicating is read math sentences of multiplication and root.
\end{abstract}

Keywords: scientific approach; 2013 curriculum; sequences and series 


\section{PENDAHULUAN}

Sistem kurikulum di Indonesia saat ini telah mengalami pengembangan dari Kurikulum 2006 menjadi Kurikulum 2013. Pada kurikulum sebelumnya, guru lebih banyak berperan dalam penyampaian materi di depan kelas, namun pada Kurikulum 2013 siswalah yang dituntut untuk berperan aktif. Keaktifan siswa dapat dinilai dari peranannya dalam mengikuti kegiatan pembelajaran. Siswa dituntut untuk dapat melaksanakan lima langkah pembelajaran yang meliputi mengamati, menanya, mengumpulkan informasi, mengasosiasi atau menalar, dan mengkomunikasikan. Kelima langkah tersebut merupakan langkah-langkah dalam pendekatan saintifik, yaitu pendekatan pembelajaran yang digunakan pada Kurikulum 2013. Kegiatan pembelajaran dengan pendekatan saintifik dipaparkan sebagai berikut.

\section{Mengamati}

Kegiatan mengamati dalam pembelajaran sebagaimana disampaikan dalam Peraturan Menteri Pendidikan dan Kebudayaan No. 81A tahun 2013 dilakukan dengan menyimak, membaca, melihat, atau mendengar terkait materi pembelajaran yang disajikan baik menggunakan alat peraga atau tidak. Menurut Imran (2014) kegiatan ini menitikberatkan pada kebermaknaan proses pembelajaran karena memiliki kelebihan seperti menyajikan objek dengan media secara nyata, membuat siswa merasa senang dan tertantang, serta mudah dalam pelaksanaannya, sehingga sangat bermanfaat untuk memenuhi rasa ingin tahu siswa.

\section{Menanya}

Menurut Peraturan Menteri Pendidikan dan Kebudayaan No. 81A tahun 2013 dalam langkah menanya siswa diajak untuk mengajukan pertanyaan mengenai informasi yang belum dapat dipahami atau untuk memperoleh informasi tambahan dari apa yang telah diamati. Melalui kegiatan ini, rasa ingin tahu siswa dapat dikembangkan. Pertanyaan yang diajukan oleh siswa menjadi dasar untuk mencari informasi lebih lanjut dan beragam dari berbagai sumber (Imran, 2014).

\section{Mengumpulkan Informasi}

Menurut Peraturan Menteri Pendidikan dan Kebudayaan No. 81A tahun 2013, kegiatan mengumpulkan informasi dapat dilakukan dengan berbagai cara seperti melakukan pengamatan terhadap suatu objek atau kejadian, eksperimen, wawancara dengan narasumber, atau membaca sumber informasi lain selain buku teks. Kegiatan mengumpulkan informasi penting bagi siswa karena interaksi siswa dengan berbagai macam sumber belajar dapat mendorong siswa untuk belajar dan mempercepat pemahaman serta penguasaan materi yang diperlukan sehingga hasil belajar menjadi lebih optimal (Sanjaya, 2015).

\section{Mengasosiasi atau Menalar}

Kegiatan menalar dalam Kurikulum 2013 merujuk pada pembelajaran asosiatif, yaitu pembelajaran yang mengacu pada kemampuan mengelompokkan beragam ide dan menghubungkan beragam peristiwa untuk kemudian mengubahnya menjadi suatu penggalan memori (Imran, 2014). Menurut Peraturan Menteri Pendidikan dan Kebudayaan No. 81A tahun 2013 dalam langkah mengasosiasi atau menalar, siswa mengolah informasi yang sudah dikumpulkan dari yang bersifat menambah keluasan dan kedalaman hingga mencari solusi dari berbagai sumber, serta menghubungkan informasi yang satu dengan informasi yang lainnya untuk menemukan suatu pola.

\section{Mengkomunikasikan}

Menurut Peraturan Menteri Pendidikan dan Kebudayaan No. 81A tahun 2013 kegiatan mengkomunikasikan berupa penyajian hasil pengamatan yang meliputi proses, hasil, dan kesimpulan secara lisan, tertulis, maupun menggunakan media lainnya. Melalui pendekatan saintifik diharapkan kemampuan komunikasi siswa dapat dikembangkan, sehingga penting bagi guru untuk memberikan kesempatan kepada siswa dalam mengkomunikasikan apa yang telah mereka pelajari. Dalam pembelajaran matematika terdapat istilah ko- 
munikasi matematis. Komunikasi matematis dapat diartikan sebagai cara untuk menyampaikan ide-ide pemecahan masalah, strategi maupun solusi matematika baik secara tertulis maupun lisan (Imran, 2014). Kemampuan komunikasi matematis dalam pemecahan masalah menurut National Council of Teachers of Mathematics dalam Imran (2014) salah satunya dapat dilihat dalam penggunaaan kalimat matematika untuk menyatakan ide matematika dengan tepat.

Penerapan pendekatan saintifik bertujuan untuk membiasakan siswa berpikir, bersikap, serta berkarya dengan menggunakan kaidah dan langkah ilmiah sehingga proses pembelajaran menjadi lebih penting dibandingkan hasil pembelajaran (Musfiqon \& Nurdyansyah, 2015). Selain itu, pembelajaran dengan pendekatan saintifik juga bertujuan untuk memberikan pemahaman kepada siswa bahwa informasi bisa berasal darimana saja dan kapan saja, tidak bergantung pada informasi searah dari guru sehingga pembelajaran diarahkan untuk mendorong siswa dalam mencari tahu dari berbagai sumber, dan bukan hanya diberi tahu (Budiyanto, dkk, 2016). Dengan diterapkannya pendekatan saintifik diharapkan siswa dapat lebih aktif dalam mengikuti kegiatan pembelajaran sehingga pembelajaran menjadi lebih bermakna.

Apabila pembelajaran dengan pendekatan saintifik dapat dilakukan dengan baik dan benar maka akan memungkinkan siswa lebih aktif, kemampuan penalaran matematiknya terus terasah, serta kemampuan komunikasinya menjadi terlatih baik saat memberikan jawaban, tanggapan atau saat mendengarkan penjelasan dari siswa lain (Imran, 2014). Akan tetapi, pembelajaran dengan pendekatan saintifik nyatanya belum dapat terealisasikan sesuai rencana terutama pada mata pelajaran matematika. Berdasarkan hasil wawancara dengan guru, diperoleh informasi bahwa selama pembelajaran matematika menggunakan pendekatan saintifik, beberapa siswa belum dapat menyesuaikan diri dengan sistem pembelajarannya. Hal ini juga didukung oleh hasil penelitian Rumahlatu, et al (2016) yang menyatakan bahwa salah satu faktor penghambat dalam pelaksanaan pendekatan saintifik adalah kesiapan mental siswa yang belum disiap- kan secara optimal. Kesiapan mental siswa yang dimaksud disini adalah kesiapan belajar siswa dalam mengikuti pembelajaran dengan pendekatan saintifik.

Menurut Slameto dalam Widyaningtyas, dkk (2013) kesiapan belajar siswa merupakan salah satu faktor internal yang mempengaruhi belajar. Tingkat kesiapan belajar siswa akan berpengaruh terhadap prestasi belajar. Padahal pencapaian prestasi belajar yang maksimal merupakan tujuan dari setiap kegiatan belajar (Widyaningtyas, dkk, 2013). Oleh karena itu, kesiapan siswa dalam mengikuti pembelajaran akan berpengaruh pada tujuan pembelajaran yang ingin dicapai. Setiap mata pelajaran yang diajarkan di sekolah memiliki tujuan pembelajaran yang berbedabeda. Dalam pembelajaran matematika, tujuan pembelajaran sesuai yang dirumuskan oleh Permendiknas nomor 22 tahun 2006 salah satunya adalah memahami konsep matematika (Choridah, 2013).

Pemahaman konsep matematika merupakan landasan penting dalam menyelesaikan permasalahan matematika maupun permasalahan sehari-hari. Namun pada kenyataannya, salah satu masalah pokok dalam pembelajaran matematika adalah masih rendahnya daya serap dan pemahaman siswa terhadap konsep matematika (Hadi \& Kasum, 2015). Salah satu materi pembelajaran matematika yang pemahaman siswa terhadap konsepnya masih rendah adalah barisan dan deret geometri. Hal ini didukung oleh hasil penelitian Nopriana et al (2016) yaitu dalam menyelesaikan permasalahan barisan dan deret geometri pada tahap pemahaman konsep sebagian besar siswa mengalami kesulitan dalam memahami masalah. Selain itu, Sudarsana, dkk (2017) juga menyatakan bahwa salah satu kompetensi yang belum dikuasai dengan baik oleh siswa adalah tentang materi barisan dan deret geometri karena siswa masih mengalami kesulitan dalam mempelajari dan memahami konsep sehingga siswa cenderung menghafalkan rumus. Pada penelitian ini peneliti akan fokus meneliti mengenai bagaimana kendala penerapan pendekatan saintifik dalam pembelajaran barisan dan deret geometri. Penelitian ini diharapkan dapat menjadi masukan bagi sekolah, guru, siswa, 
dan pengambil kebijakan pada umumnya untuk perbaikan dimasa yang akan datang.

\section{METODE}

Metode penelitian ini adalah penelitian kualitatif dengan pendekatan studi kasus. Sumber data dalam penelitian ini terdiri dari data primer yaitu siswa kelas X SMK Negeri 1 Purworejo yang diambil dengan teknik snowball dan data sekunder yaitu guru sebagai informan.

\section{Teknik Pengumpulan Data}

Pengumpulan data dalam penelitian ini dilakukan dengan observasi (pengamatan), wawancara, dan dokumentasi. Dalam melakukan observasi, objek penelitiannya adalah aktivitas siswa di kelas selama proses pembelajaran barisan dan deret geometri dengan pendekatan saintifik. Data yang dicari oleh peneliti berfokus pada kendala penerapan pendekatan saintifik dalam pembelajaran barisan dan deret geometri. Adapun instrumen yang digunakan adalah pedoman observasi terfokus. Kemudian untuk wawancara, peneliti menggunakan wawancara tidak terstruktur yang dilakukan terhadap guru dan siswa untuk menggali lebih dalam mengenai kendala penerapan pendekatan saintifik dalam pembelajaran barisan dan deret geometri dari hasil observasi pembelajaran di kelas yang telah dilakukan sebelumnya. Data dari hasil observasi dan wawancara yang diperoleh kemudian dilengkapi dengan dokumentasi. Dalam penelitian ini, dokumen penelitian berbentuk foto, video, hasil diskusi siswa, dan buku siswa untuk mendukung dan menguatkan data yang dikumpulkan peneliti.

\section{Instrumen Penelitian}

Dalam penelitian kualitatif, yang menjadi instrumen penelitian adalah peneliti itu sendiri karena segala sesuatunya seperti masalah, fokus penelitian, prosedur penelitian, hipotesis yang digunakan, bahkan hasil yang diharapkan belum mempunyai bentuk yang tidak pasti dan masih perlu untuk dikembangkan selama penelitian itu (Sugiyono, 2017). Namun setelah fokus penelitian menjadi jelas, dapat dikembangkan instrumen penelitian sederhana yang diharapkan dapat meleng- kapi data dan membandingkan dengan data yang telah ditemukan melalui observasi dan wawancara. Dalam penelitian ini, peneliti menggunakan instrumen pendukung berupa pedoman observasi.

\section{Teknik Analisis Data}

Langkah-langkah yang dilakukan dalam menganalisis data terdiri dari data reduction, data display, dan conclusion drawing/ verification.

Data Reduction (Reduksi Data). Reduksi data dilakukan dengan cara merangkum, memilih hal-hal yang pokok, memfokuskan pada hal-hal yang penting, dicari tema dan polanya sehingga akan memberikan gambaran yang lebih jelas, dan mempermudah peneliti untuk melakukan pengumpulan data selanjutnya, serta mencarinya bila diperlukan (Sugiyono, 2017).

Data Display (Penyajian Data). Penyajian data dilakukan untuk memudahkan dalam memahami apa yang terjadi, merencanakan kerja selanjutnya berdasarkan apa yang telah difahami tersebut (Sugiyono, 2017). Pada langkah ini, peneliti berusaha menyusun data yang telah direduksi sehingga menjadi informasi yang dapat disimpulkan dan memiliki makna tertentu.

Conclusion Drawing/ Verification (Penarikan Kesimpulan). Langkah selanjutnya yaitu penarikan kesimpulan dan verifikasi. Menurut Sugiyono (2017), kesimpulan dalam penelitian kualitatif merupakan temuan baru yang sebelumnya belum pernah ada, berupa deskripsi atau gambaran suatu objek yang sebelumnya masih remang-remang atau gelap sehingga setelah diteliti menjadi jelas.

\section{HASIL DAN PEMBAHASAN}

Berdasarkan penelitian mengenai kendala penerapan pendekatan saintifik dalam pembelajaran barisan dan deret geometri diperoleh hasil sebagai berikut.

\section{Mengamati}

Dari hasil observasi di kelas saat pelaksanaan pembelajaran barisan dan deret geometri dengan pendekatan saintifik, sebagian besar siswa ikut dalam mengamati perma- 
salahan yang diberikan meskipun masih ada yang mengobrol atau cenderung diam. Siswa mengamati beberapa permasalahan secara berkelompok tanpa menggunakan alat peraga. Berdasarkan hasil wawancara terhadap para siswa, diperoleh jawaban yang serupa bahwa dalam kegiatan mengamati akan lebih mudah jika dilakukan secara berkelompok seperti yang dikemukakan oleh siswa $2\left(\mathrm{~S}_{2}\right)$ berikut.

P: $\quad$ "Saat proses pembelajaran, kamu diminta untuk mengamati beberapa permasalahan yang diberikan, apa yang kamu rasakan ketika mengamati?"

$\mathrm{S}_{2}$ : "Kalau bareng-bareng lebih mudah gitu."

Kemudian berdasarkan hasil wawancara terhadap guru, diperoleh informasi bahwa dalam kegiatan mengamati siswa tidak terkendala karena siswa hanya melihat atau mendengar permasalahan yang diberikan. Berikut kutipan wawancara yang peneliti lakukan terhadap guru (G).

P: "Kalau dalam tahap mengamati kendalanya apa ya bu?"

G : $\quad$ "Kalau mengamati tidak banyak kendala mbak karena mengamati itu kan kita menyampaikan masalah bisa dengan cara anak melihat atau anak mendengarkan, gitu kan. Jadi udah gak masalah."

\section{Menanya}

Dari hasil observasi di kelas saat pelaksanaan pembelajaran barisan dan deret geometri dengan pendekatan saintifik, siswa masih kurang aktif dalam kegiatan menanya. Hanya ada satu siswa yang bertanya kepada salah satu kelompok yang menyampaikan hasil diskusinya di depan kelas untuk mendapatkan informasi tambahan yang ingin diketahui pada observasi ke-1. Berdasarkan hasil wawancara terhadap guru, ketika diberikan kesempatan untuk bertanya siswa masih bingung dengan apa yang ingin ditanyakan sehingga bimbingan dari guru agar siswa dapat aktif bertanya sangat diperlukan. Berikut kutipan wawancara yang peneliti lakukan terhadap guru (G).
P : Kalau dalam tahap menanya kelihatannya siswa masih kurang aktif, itu masih kurang mendapat arahan atau bagaimana?"

G : "Itu dia melihat masalah, dia sendiri bingung apa yang mau ditanyakan. Jadi, harus gurunya aktif mancing-mancing pertanyaan. Nanti dia baru merespon tanya. Jadi kalau tidak dipancing-pancing jarang anak melihat masalah bisa langsung bertanya."

Kemudian dari hasil wawancara dengan para siswa, mereka juga menyatakan bahwa masih bingung dengan apa yang ingin ditanyakan ketika diberikan kesempatan untuk bertanya, seperti yang dikemukakan oleh siswa 4 $\left(\mathrm{S}_{4}\right)$ berikut.

P: "Ketika diberikan kesempatan untuk bertanya terkait materi pembelajaran, apakah kamu tahu apa yang harus ditanyakan?"

\section{$\mathrm{S}_{4}$ : $\quad$ "Bingung mau tanya apa."}

Sedangkan siswa-siswa lainnya menyatakan bahwa dalam kegiatan menanya mereka terkendala dalam merumuskan pertanyaan terkait banyaknya suku, jumlah suku pertama, serta rasio. Hal ini terlihat dalam kutipan wawancara yang peneliti lakukan terhadap siswa $1\left(\mathrm{~S}_{1}\right)$, siswa $2\left(\mathrm{~S}_{2}\right)$, dan siswa $3\left(\mathrm{~S}_{3}\right)$ berikut.

P : $\quad$ "Ketika diberikan kesempatan untuk bertanya terkait materi pembelajaran, apa kamu tahu yang harus ditanyakan apa?"

$\mathrm{S}_{1}$ : "Tahu."

P: $\quad$ "Ketika merasa kesulitan, kamu bertanya kepada guru atau lebih memilih bertanya kepada teman?"

$\mathrm{S}_{1}$ : $\quad$ "Tanya pada teman, kalau kepada guru susah buat pertanyaannya."

P : Terkait permasalahan yang sudah diberikan, adakah kendala yang kamu alami dan ingin kamu tanyakan kepada guru ketika proses pembelajaran kemarin?" 
$\mathrm{S}_{1}$ : $\quad$ Permasalahan ke-2 itu bingung nyari Unya berapa, terus 2 amoeba itu menit ke-o apa gimana gitu, bingung ngomongnya."

P: "Ketika diberikan kesempatan untuk bertanya terkait materi pembelajaran, apakah kamu tahu apa yang harus ditanyakan?"

$\mathrm{S}_{2}$ : "Ya kadang-kadang ada tapi susah itu membicarakan. Mencari kata-katanya itu susah."

P: "Terkait permasalahan yang sudah diberikan, adakah kendala yang kamu alami dan ingin kamu tanyakan kepada guru ketika proses pembelajaran kemarin?"

$\mathrm{S}_{2}$ : $\quad$ "Permasalahan ke-3 ini nyari jumlah $n$ suku yang pertama itu nyari Uınya apa gimana gitu."

P: "Ketika diberi kesempatan untuk bertanya terkait materi pembelajaran, apa kamu tahu apa yang harus ditanyakan?"

$\mathrm{S}_{3}$ : "Terkadang gak tahu."

P: $\quad$ "Terkait permasalahan yang sudah diberikan, adakah kendala yang kamu alami dan ingin kamu tanyakan kepada guru ketika proses pembelajaran kemarin?"

$\mathrm{S}_{3}$ : "Tanya rasionya yang mana."

\section{Mengumpulkan Informasi}

Dari hasil observasi di kelas saat pelaksanaan pembelajaran barisan dan deret geometri dengan pendekatan saintifik, dalam mengumpulkan informasi sumbernya hanya berasal dari guru dan teman sekelompoknya melalui kegiatan diskusi. Saat pembelajaran berlangsung guru tidak mempersilakan siswa untuk menggunakan internet padahal siswa tidak memiliki buku pegangan untuk belajar. Berdasarkan hasil wawancara terhadap guru, diperoleh informasi bahwa sebenarnya sekolah memiliki buku siswa yang sesuai dengan Kurikulum 2013 dan jumlahnya sesuai dengan jumlah siswa, tetapi buku tersebut tidak dibagikan lagi kepada siswa karena sulit untuk dipahami siswa. Sedangkan buku lain yang lebih mudah dipahami oleh siswa ada tetapi tidak sesuai dengan Kurikulum 2013 serta jumlahnya tidak sebanyak siswa sehingga tidak diba- gikan dan hanya ada di perpustakaan. Berikut kutipan wawancara yang peneliti lakukan terhadap guru (G).

P : $\quad$ "Kemudian dalam mengumpulkan informasi kan tidak ada buku pegangan buat belajar siswa, lalu itu gimana Bu?"

$G$ : "Dulu ada buku siswa."

P : "Itu buku siswanya sudah sesuai K13 ya Bu?"

G: $\quad$ "Sesuai tapi lebih susah dipahami anak. Buku siswa ada di perpus. Awalnya sudah tiap tahun dipake cuman kendalanya lebih mudah dipahami itu buku yang lama, buku lain yang relevan. Jadi buku siswanya malah justru sekarang tidak dibagikan lagi karena anak baca aja gak paham. Misalnya kalau dulu itu kan soalnya terlalu sederhana, jadi anak bisa memahami kalau sekarang kayak soal OSN itu. Jadi lebih tinggi tarafannya. Jadi anak lebih bisa memahami buku yang lain. Tapi kalau buku yang lain yang relevan kan tidak sejumlah siswa, jadi gak dibagikan. Cuma kalau anak butuh bisa pinjem ke perpustakaan, gitu."

Kemudian dari hasil wawancara terhadap para siswa, diperoleh jawaban yang serupa bahwa mereka merasa terkendala dalam kegiatan mengumpulkan informasi karena kurang optimalnya penggunaan buku teks dan internet seperti yang dikemukakan oleh siswa $4\left(\mathrm{~S}_{4}\right)$ berikut.

$$
\begin{aligned}
& \mathrm{P}: \text { "Untuk buku materi pembelajaran kan ti- } \\
& \text { dak ada, apa kamu menjadi merasa terken- } \\
& \text { dala dalam mencari informasi terkait ma- } \\
& \text { teri pembelajaran?" } \\
& \mathrm{S}_{4}: \text { "Ya sangat, sangat terkendala." }
\end{aligned}
$$

\section{Mengasosiasi atau Menalar}

Dari hasil observasi dan dokumentasi hasil diskusi siswa di kelas saat pelaksanaan pembelajaran barisan dan deret geometri dengan pendekatan saintifik, dalam kegiatan mengasosiasi atau menalar siswa mengalami kendala pada beberapa permasalahan. Berdasarkan hasil observasi ke-1, siswa mengalami kendala pada permasalahan berikut. 
Sebuah mobil dibeli dengan haga Rp. $80.000 .000,00$. Setiap tahun nilai jualnya menjedi $3 / 4$ dari harga sebelumnya. Berapa nilai jual setelah dipakai 3 tahun ?

Gambar 1. Permasalahan ke-1 yang menjadi Kendala Siswa

Hasil pekerjaan siswa pada permasalahan tersebut adalah sebagai berikut.

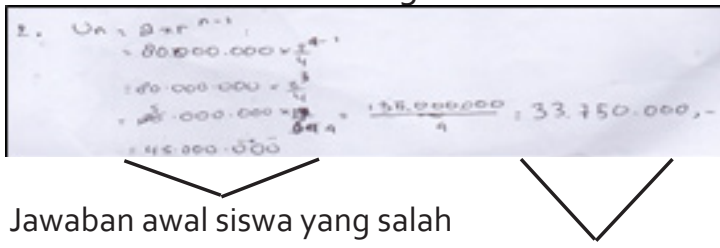

Jawaban akhir setelah pembetulan

Gambar 2. Hasil Penyelesaian Kelompok Siswa pada Permasalahan ke-1

Dari gambar tersebut dapat dilihat bahwa siswa awalnya mendapatkan hasil akhir, namun hasil tersebut salah dan kemudian siswa memberikan pembetulan setelah permasalahan tersebut dibahas sehingga diperoleh hasil .

Kendala lain yang dialami siswa ketika observasi ke-1 terletak pada permasalahan berikut.

Sẹbuah amoeba dapat membelah diri menjadi 2 setiap 6 menit. Pertanyaannya, berapakah jumlah amoeba setelah satu jam jika pada awalnya terdapat 2 amoeba?

Gambar 3. Permasalahan ke-2 yang menjadi Kendala Siswa

Pada permasalahan tersebut hampir semua siswa memberikan hasil akhir 1024 amoeba. Rincian pekerjaan awal siswa yaitu sebagai berikut.

$$
\begin{aligned}
U_{10} & =2 \times 2^{(10-1)} \\
& =2 \times 2^{9} \\
& =2 \times 512 \\
& =1024
\end{aligned}
$$

Kemudian setelah permasalahan tersebut dibahas bersama-sama, siswa memberikan pembetulan pada pekerjaannya dengan mengganti (banyaknya suku) yang awalnya
10 menjadi 11 yang diperoleh dari

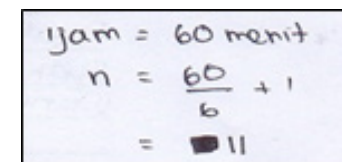

Gambar 4. Pembetulan untuk Memperoleh Nilai pada Permasalahan ke-2

sehingga diperoleh hasil akhirnya 2048 amoeba. Berikut adalah bukti dari pekerjaan siswa pada permasalahan ke-2.

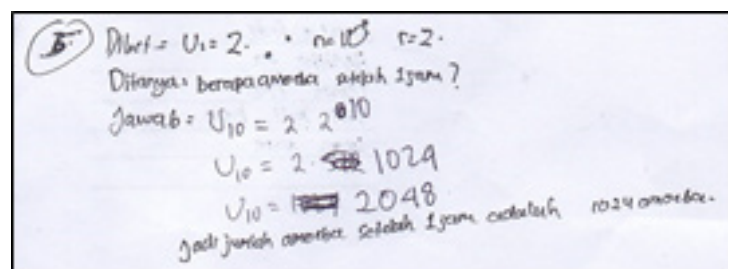

Gambar 5. Pembetulan Hasil Penyelesaian Siswa pada Permasalahan ke-2

Pekerjaan siswa pada kedua permasalahan tersebut menunjukkan bahwa siswa terkendala dalam menentukan nilai (banyak suku) apabila dalam permasalahan tidak disebutkan dengan jelas nilai yang diminta. Dua permasalahan tersebut merupakan permasalahan barisan dan deret geometri dalam kehidupan nyata. Hal ini menunjukkan bahwa siswa terkendala dalam menentukan banyaknya suku pada permasalahan kehidupan nyata. Hal ini didukung oleh hasil wawancara yang dilakukan terhadap para siswa yang menyatakan bahwa mereka terkendala dalam menerapkan materi yang didapat dengan kehidupan sehari-hari. Berikut kutipan wawancara yang peneliti lakukan terhadap siswa 1 $\left(\mathrm{S}_{1}\right)$ dan siswa $3\left(\mathrm{~S}_{3}\right)$.

P: "Saat mencoba mengerjakan permasalahan yang diberikan, digunakan beberapa teori, kendala atau kesulitan apa yang kamu alami?"

$\mathrm{S}_{1}$ : "Bingung penerapannya." 
P: "Saat mencoba mengerjakan permasalahan yang diberikan, digunakan beberapa teori, kendala atau kesulitan apa yang kamu alami?"

$\mathrm{S}_{3}$ : "Kesulitannya bingung dalam pelajaran itu diterapkan ke soal kehidupan sehari-hari."

Kendala siswa dalam menentukan banyaknya suku juga peneliti temukan dari hasil observasi ke-3. Berikut adalah permasalahan ke-3 yang menjadi kendala siswa.

Dalam deret qometri diketahui suku $k e-2=10$ dan suku ke-s $=1.250$. Jumlah $n$ suku yang pertama deret tersebut adalah..

Gambar 6. Permasalahan ke-3 yang menjadi Kendala Siswa

Hasil pekerjaan kelompok siswa pada permasalahan tersebut adalah sebagai berikut.

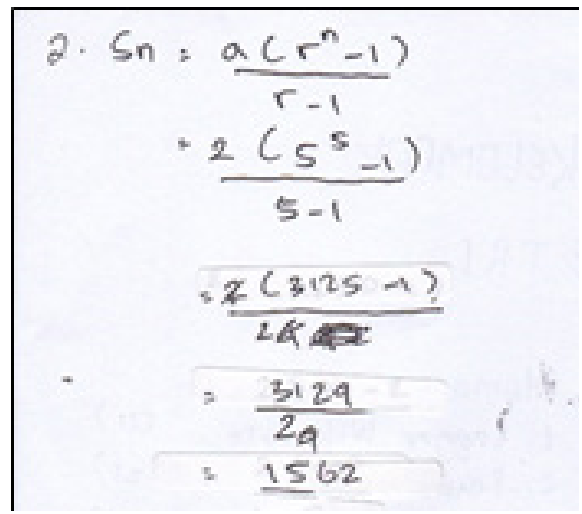

Gambar 7. Hasil Pekerjaan Kelompok Siswa ke-1 pada Permasalahan ke-3

Pada permasalahan tersebut siswa diminta untuk mencari jumlah (banyaknya suku) suku yang pertama dari deret tersebut, dimana (banyaknya suku) yang dimaksud tidak bernilai angka sehingga hasil akhirnya berupa rumus. Tetapi siswa menganggap bahwa (banyaknya suku) yang diminta dalam permasalahan tersebut adalah 5 sehingga jawaban akhirnya salah. Dilihat dari pekerjaan siswa pada ketiga permasalahan tersebut, ternyata siswa mengalami kendala dalam menentukan banyaknya suku.
Dari hasil observasi ke-3 dan dokumentasi hasil diskusi siswa di kelas saat pelaksanaan pembelajaran barisan dan deret geometri, dalam kegiatan mengasosiasi atau menalar siswa juga mengalami kendala dalam menggunakan rumus barisan dan deret. Hal ini dapat dilihat dari hasil pekerjaan siswa pada permasalahan ke-3 berikut ini.

$$
\text { (2) } \begin{aligned}
U_{2} & =10 \\
U_{s} & =1.250 \\
a+b & =10 \\
a+4 b & =1.250 \\
-3 b & =-1240 \\
b & =4
\end{aligned}
$$

Gambar 8. Hasil Pekerjaan Kelompok Siswa ke-2 pada Permasalahan ke-3

Dari pekerjaan siswa tersebut, dapat dilihat bahwa dalam menyelesaikan permasalahan ke-3 siswa menggunakan rumus deret aritmetika sehingga yang mereka cari adalah nilai (suku pertama) dan (beda), padahal yang sedang dipelajari dan diminta pada permasalahan tersebut adalah deret geometri. Dari sini dapat dikatakan bahwa siswa masih terkendala dalam membedakan rumus barisan dan deret aritmetika dengan rumus barisan dan deret geometri yang harus digunakan dalam penyelesaian permasalahan. Hal ini didukung oleh hasil wawancara yang dilakukan terhadap siswa yang menyatakan bahwa mereka terkendala dalam menentukan rumus yang harus digunakan dalam penyelesaian permasalahan. Berikut kutipan wawancara yang peneliti lakukan terhadap siswa $2\left(\mathrm{~S}_{2}\right)$ dan siswa $4\left(\mathrm{~S}_{4}\right)$.

P: "Saat mencoba mengerjakan permasalahan yang diberikan, digunakan beberapa teori atau rumus, kendala yang kamu alami apa?"

$\mathrm{S}_{2}$ : "Ketika mengerjakan rumusnya lupa."

P: "Saat mencoba mengerjakan permasalahan yang diberikan digunakan beberapa teori atau rumus, kendala apa yang kamu alami disitu?" 


\section{$\mathrm{S}_{4}:$ "Ya itu kalau gak hafal rumusnya."}

Kemudian berdasarkan hasil wawancara dengan guru, adanya kendala dalam mengasosiasi atau menalar menandakan bahwa siswa sangat membutuhkan bimbingan dari guru. Siswa akan mengalami banyak kendala jika guru melepas siswa untuk melakukan kegiatan ini tanpa dibimbing. Berikut kutipan wawancara yang peneliti lakukan terhadap guru (G).

\section{P : $\quad$ "Kalau dalam tahap mengasosiasi atau me- nalar apakah menurut Ibu masih ada ken- dala yang dialami siswa dalam mengaitkan antar konsep atau teori?" \\ G : "Nah itu anak jelas sulit, masih gak bisa dilepas anak."}

\section{Mengkomunikasikan}

Dari hasil observasi di kelas saat pelaksanaan pembelajaran barisan dan deret geometri dengan pendekatan saintifik, dalam mengkomunikasikan belum terlihat adanya kemauan dari diri siswa untuk mengemukakan pendapatnya. Hal ini dikarenakan untuk maju ke depan kelas, siswa harus ditunjuk terlebih dahulu agar mereka bersedia. Berdasarkan hasil wawancara terhadap para siswa, diperoleh jawaban yang serupa bahwa mereka merasa kurang percaya diri dalam mengemukakan pendapatnya di depan kelas seperti yang dikemukakan oleh siswa $2\left(\mathrm{~S}_{2}\right)$ berikut.

\section{P : $\quad$ "Saat proses pembelajaran, kalian dimin- ta untuk menyajikan laporan hasil diskusi atau kesimpulan pembelajaran, apa yang kamu rasakan?" \\ $\mathrm{S}_{2}$ : "Kalau menerangkan proses penyelesa- ian hasil diskusi sama ringkasannya ma- sih sulit karena kurang percaya diri lah, kadang diejek sama temen gitu jadi salah tingkah."}

Berdasarkan hasil observasi, siswa menyampaikan laporan hasil diskusi dan kesimpulan pembelajaran dengan singkat dan jelas, namun terkendala dalam pembacaan kalimat matematika yang masih kurang tepat. Hal ini terbukti ketika siswa membaca kalimat matematika perkalian dan akar masih sering mengalami kesalahan. Pada observasi ke-1, ketika menyampaikan kesimpulan pembelajaran siswa membaca dengan "akar" dan dibaca " akar". Kemudian pada observasi ke-2, ketika menyampaikan laporan hasil diskusi siswa membaca dengan "sama dengan min 1 per min 1 " serta beberapa kesalahan dalam pembacaan akar seperti yang dibaca "akar 2 kali 128", dibaca "suku tengah adalah akar dari suku pertama kali suku ke-", bahkan ada yang membacanya "suku tengah sama dengan kali diakar". Pada observasi ke-3, ketika menyampaikan laporan hasil diskusi siswa juga masih terkendala dalam membaca akar seperti dibaca "rasio baru sama dengan akar dari " serta yang dibaca "16 akar 4". Selain itu, hasil observasi menunjukkan bahwa dalam menyampaikan laporan hasil diskusi dan kesimpulan pembelajaran siswa juga masih terkendala dalam kemampuan berbahasa Indonesia dengan baik dan benar, dimana hal ini didukung oleh hasil wawancara yang dilakukan terhadap guru. Berikut kutipan wawancara yang peneliti lakukan terhadap guru.

\section{P: "Kalau dalam mengkomunikasikan sendiri kendalanya apa ya Bu?" \\ G : "Kalau mengkomunikasikan biasanya siswa itu tidak berbahasa Indonesia dengan baik dan benar. Jadi kadang campur-campur ada jawanya juga ada, kadang bahasa jawa halusnya juga hilang."}

Berdasarkan hasil observasi, rekaman hasil wawancara, dokumentasi hasil diskusi dan buku siswa, serta triangulasi data, dalam pelaksanaan pembelajaran barisan dan deret geometri dengan pendekatan saintifik yang terdiri dari langkah mengamati, menanya, mengumpulkan informasi, mengasosiasi atau menalar, dan mengkomunikasikan ada beberapa kendala yang dialami oleh para siswa. Dalam kegiatan mengamati, siswa tidak mengalami kendala karena mereka hanya melihat atau mendengar permasalahan yang diberikan. Hasil penelitian ini berbeda dengan hasil penelitian Krisdiana, dkk (2014) yang menyatakan bahwa dalam kegiatan mengamati terdapat kendala berupa kesulitan siswa dalam memahami permasalahan yang diamati karena sebelumnya siswa jarang dilibatkan dalam kegiatan pengamatan dan guru masih 
menganggap bahwa materi matematika sulit dipahami jika diterapkan dengan metode mengamati.

Dalam kegiatan menanya beberapa siswa masih bingung dengan apa yang ingin ditanyakan. Beberapa siswa juga terkendala dalam merumuskan pertanyaan terkait banyaknya suku, jumlah suku pertama, serta rasio. Hasil penelitian ini sedikit berbeda dengan hasil penelitian Cholifah et al (2013) yang menyatakan bahwa dalam kegiatan menanya masih banyak siswa yang mengalami kesulitan dalam mengungkapkan pertanyaan.

Selama pembelajaran di kelas, siswa mengumpulkan informasi dari guru dan teman melalui kegiatan diskusi. Siswa tidak memiliki buku pegangan untuk belajar yang sesuai dengan Kurikulum 2013. Saat pembelajaran berlangsung guru juga tidak mempersilakan siswa untuk menggunakan internet sebagai sarana untuk mengumpulkan informasi sehingga siswa mengalami kendala karena kurang optimalnya penggunaan buku teks dan internet. Hasil penelitian ini sejalan dengan hasil penelitian Krisdiana et al (2014) yang menyatakan bahwa dalam mengumpulkan informasi terdapat kendala berupa kurangnya penggunaan teknologi informasi.

Dalam kegiatan mengasosiasi atau menalar, masih banyak siswa yang terkendala dalam menghubungkan antar konsep atau teori terkait penentuan banyaknya suku. Selain itu, siswa juga terkendala dalam menentukan rumus barisan dan deret yang harus digunakan dalam penyelesaian permasalahan. Hal ini sejalan dengan hasil penelitian Komariah (2011) yang menyatakan bahwa kendala dalam menghubungkan antar konsep dalam matematika menyebabkan siswa kesulitan dalam menyusun strategi pemecahan masalah. Hasil penelitian lain yang sejalan yaitu hasil penelitian Khasanah \& Sutama (2015) yang menyatakan bahwa kurangnya kemampuan siswa dalam menghubungkan konsep menyebabkan siswa terkendala untuk menentukan rumus yang digunakan dalam penyelesaian permasalahan.

Dalam kegiatan mengkomunikasikan, siswa masih terkendala dalam membaca kalimat matematika perkalian dan akar. Hasil penelitian ini sedikit berbeda dengan hasil penelitian Ulya (2016) yang menyatakan bahwa ketika kegiatan mengkomunikasikan siswa mengalami kendala dalam menuliskan penyelesaian dalam bahasa matematika. Menurut National Council of Teachers of Mathematics dalam Imran (2014) penggunaan kalimat matematika untuk menyatakan ide matematika dengan tepat merupakan salah satu kemampuan komunikasi matematis dalam pemecahan masalah. Sehingga kendala siswa dalam membaca kalimat matematika menandakan bahwa kemampuan komunikasi matematis siswa masih perlu untuk ditingkatkan.

\section{PENUTUP}

\section{Simpulan}

Berdasarkan hasil penelitian dapat disimpulkan bahwa dalam pembelajaran barisan dan deret geometri dengan pendekatan saintifik, tidak terdapat kendala dalam kegiatan mengamati. Kendala terjadi pada keempat langkah lainnya yaitu berupa: (1) Kendala dalam menanya yaitu merumuskan pertanyaan terkait banyaknya suku, jumlah suku pertama, serta rasio; (2) Kendala dalam mengumpulkan informasi yaitu kurang optimalnya penggunaan buku teks dan internet; (3) Kendala dalam mengasosiasi atau menalar yaitu menentukan banyaknya suku dan menentukan rumus barisan dan deret yang digunakan dalam penyelesaian permasalahan; serta (4) Kendala dalam mengkomunikasikan yaitu membaca kalimat matematika perkalian dan akar.

\section{Saran}

Berdasarkan hasil penelitian dan pembahasan, maka disarankan hal-hal sebagai berikut: (1) Guru hendaknya dapat memberikan fasilitas pencapaian tujuan belajar dengan membuat suatu inovasi seperti menggunakan alat peraga, mengadakan permainan, dan lain-lain agar dapat meningkatkan rasa ingin tahu dan ketertarikan siswa dalam belajar; (2) Siswa diharapkan dapat meningkatkan kesadaran diri akan pentingnya belajar dan terlibat dalam semua aktivitas pembelajaran; dan (3) Para peneliti dapat memantapkan atau meneruskan hasil penelitian ini dengan melakukan pengembangan atau pengkajian yang lebih mendalam. 


\section{DAFTAR PUSTAKA}

Budiyanto, M. A. K., Waluyo, L., \& Mokhtar, A. (2016) Implementasi Pendekatan Saintifik dalam Pembelajaran di Pendidikan Dasar di Malang. Proceeding Biology Education Conference, 13, 46-51. Malang: Universitas Muhammadiyah Malang.

Cholifah, S., Hendri, W., \& Deswati, L. (2013). Analisis Faktor-faktor Penyebab Kesulitan Siswa dalam Mengungkapkan Pertanyaan pada Proses Pembelajaran Biologi Kelas VII SMP Bunda Padang. E-Journal Bunghatta, 2(4), 1-12.

Choridah, D. T. (2013). Peran Pembelajaran Berbasis Masalah untuk Meningkatkan Kemampuan Komunikasi dan Berpikir Kreatif serta Disposisi Matematis Siswa SMA. Infinity, 2(2), 194-202.

Hadi, S., \& Kasum, M. U. (2015). Pemahaman Konsep Matematika Siswa SMP melalui Penerapan Model Pembelajaran KooperatifTipe Memeriksa Berpasangan (Pair Checks). Edu-Mat Jurnal Pendidikan Matematika, 3(1), 59-66.

Imran, N. 'Afifah. (2014). Pengaruh Pendekatan Scientific terhadap Kemampuan Penalaran dan Komunikasi Matematika. Jurnal Bina Gogik, 1(2), 51-6o.

Kemendikbud. Peraturan Menteri Pendidikan dan Kebudayaan Republik Indonesia Nomor 81A Tahun 2013 Tentang Implementasi Kurikulum (2013).

Khasanah, U., \& Sutama. (2015). Kesulitan Menyelesaikan Soal Cerita Matematika pada Siswa SMP. Prosiding Seminar Nasional Pendidikan Matematika (pp. 79-89). Surakarta: Universitas Muhammadiyah Surakarta.

Komariah, K. (2011). Penerapan Metode Pembelajaran Problem Solving Model Polya untuk Meningkatkan Kemampuan Memecahkan Masalah bagi Siswa Kelas IX J di SMPN 3 Cimahi. Prosiding Seminar Nasional Penelitian, Pendidikan dan Penerapan MIPA (pp. 181-188). Yogyakarta: Universitas Negeri Yogyakarta.

Krisdiana, I., Apriandi, D., \& Setiansyah, R. K. (2014). Analisis Kesulitan yang Dihadapi oleh Guru dan
Peserta Didik Sekolah Menengah Pertama dalam Implementasi Kurikulum 2013 pada Mata Pelajaran Matematika (Studi Kasus Eks-Karesidenan Madiun). Jurnal Ilmiah Pendidikan Matematika UNIPMA, 3(1), 1-10.

Musfiqon, \& Nurdyansyah. (2015). Pendekatan Pembelajaran Saintifik. Sidoarjo: Nizamia Learning Center.

Nopriana, T., Firmasari, S., \& Tonah. (2016). Desain Bahan Ajar Berbasis Aktivitas Pemecahan Masalah pada Pokok Bahasan Barisan dan Deret. Jurnal Euclid, 2(4), 251-263.

Rumahlatu, D., Huliselan, E. K., \& Takaria, J. (2016). An Analysis of the Readiness and Implementation of 2013 Curriculum in The West Part of Seram District, Maluku Province, Indonesia. International Journal of Environmental \& Science Education, 11(12), 5662-5675.

Sanjaya, W. (2015). Perencanaan dan Desain Sistem Pembelajaran. Jakarta: Kencana.

Sudarsana, I. M., Murdiana, I. N., \& Lefrida, R. (2017). Penerapan Model Pembelajaran Kooperatif Tipe Student Teams Achievement Division (STAD) untuk Meningkatkan Hasil Belajar Siswa Kelas X IPA F SMA Negeri 1 Parigi pada Materi Barisan dan Deret. Jurnal Elektronik Pendidikan Matematika Tadulako, 5(1), 1-12.

Sugiyono. (2017). Metode Penelitian Kualitatif. Bandung: Alfabeta.

Ulya, H. (2016). Profil Kemampuan Pemecahan Masalah Siswa Bermotivasi Belajar Tinggi Berdasarkan Ideal Problem Solving. Jurnal Konseling Gusjigang, 2(1), 90-96.

Widyaningtyas, A., Sukarmin, \& Radiyono, Y. (2013). Peran Lingkungan Belajar dan Kesiapan Belajar terhadap Prestasi Belajar Fisika Siswa Kelas $X$ Sekolah Menengah Atas Negeri 1 Pati. Jurnal Pendidikan Fisika, 1(1), 136-143. 